\section{Paranormal theories}

SIR-While accepting Marks' general remarks about the standing of research into the paranormal (Nature 320, 119; 1986), I should like to comment upon some of his statements.

It is not true that there are "no theories to account for paranormal effects". In Bell's theorem and its refinements, in physics, we are confronted with a universe where local causality might not apply (for an entertaining discussion see Zukav, $\mathbf{R}$. The Dancing Wu Li Masters; Fontana, London, 1984). This allows Jung's "synchronicity" and psi phenomena to be placed within a theoretical framework, although not suggesting a mechanism.

Theories such as those above are at the same time physical and metaphysical, as they question our basic concept of reality. It is not surprising that "believers" in the paranormal are resistant to change in their core constructs, and it seems trite to add that they have "significantly higher neuroticism scores". What does that prove? Is it Marks' view that these "millions of people throughout the world" are psychologically abnormal? One would assume that the whole review could be rewritten, with relevant changes, to cover "investigating God". Believers would, no doubt, react in a similar way, based on a similar "dearth of hard evidence".

In summary, I agree with Marks' conclusion that there have been no significant discoveries made by parascience, but I think that he need not have looked for psychological reasons for belief in the paranormal. As far as I can see (adjusting one of his phrases), scientific ideas will have little chance of affecting the magical thinking from which science itself evolved, because the fundamental mysteries remain.

\section{Department of Human Metabolism and Clinical Biochemistry, University of Sheffield Medical School, Sheffield S10 2RX, UK}

SIR-In his Commentary, Marks ${ }^{\mathrm{I}}$ misrepresents the area he purports to review. A large part of the paper refers to religious and neurotic motives as explanation for the belief in the paranormal. However, similar psychiatric explanations are used to account for the need to deny these phenomena ${ }^{2.3}$. Ad hominem arguments lead nowhere.

As for Marks' more straightforward claims, they are indirectly based on a sample of works that is by no means representative. He relies on two reviews ${ }^{4.5}$ that do not address themselves to the question of repeatability in general, but rather to the specific question of whether parapsychological research involving altered states of consciousness constitutes a repeatable paradigm. Thus, these reviews
CORRESPONDENCE

deal with a narrow group of experiments. For example, Akers ${ }^{4}$ excluded all studies of highly selected subjects, thus considerably decreasing the overall significance of the results. Moreover, Hyman's ${ }^{5}$ analysis is flawed, as Honorton has demonstrated in a response which followed Hyman's paper $^{6}$, and his methods were shown by a statistician to commit the very error that he criticized in the parapsychological studies ${ }^{7}$

Marks is quite right in pointing out that parapsychology has so far failed to produce a repeatable experiment. But it is misleading to use this as an argument against the credibility of parapsychological research. Marks fails to mention highly significant results of experiments that are characterized by extraordinary instrumental sophistication and methodological rigour, as exemplified by the recent work of R.G. Jahn of Princeton University $^{8}$, and the Maimonides Hospital dream researches ${ }^{9-13}$. These works, although not yet replicated, pose a serious challenge to the sceptic.

There are four counterhypotheses by which parapsychological findings can be explained away: (1) coincidence; (2) artefact; (3) self-deception; and (4) deliberate fraud. Now, the growing sophistication and rigour of modern psi research ${ }^{14}$ is gradually ruling out the first three counterhypotheses. The fraud hypothesis (or, considering the present number of scientists involved in the field, the conspiracy hypothesis) remains as the only resort for the sceptic.

Psi or fraud? This is the real issue. Yet it is seldom presented unambiguously. Recently, Child ${ }^{15}$ has thoroughly analysed the ways in which the above parapsychological works have been treated in the sceptical literature. He has shown that they were either ignored or grossly misrepresented, and that the resort to the accusation of fraud was often made implicitly. It is deplorable that Marks' review, written after Child's grave charges have been issued, commits the same errors.

Avshalom C. Elitzur

15 Margolin St,

Rehovot 76225 ,

Israel

1. Marks, D.F. Nature 320, $199-124$ (1986)

. Greyson, B. J nerv ment Dis. $165,184-200$ (1977).

3. Eisenbud, J. Parapsychology and the Unconscious (North Atlantic Books, Berkeley, 1983)

4. Akers, C. in Advances in Parapsychological Research Vol. 4 (ed. Krippner, S.) 112 - 164 (McFarland, Jefferson, North Carolina, 1984)

5. Hyman, R. J. Parapsychol. 49, 3 - 49 (1985)

6. Honorton, C. J. Parapsychol. 49, 51 - 91 (1985).

7. Saunders, D. R. J. Parapsychol. 49, Appendix B (1985)

Jahn, R.G. Proc. IEEE 70/2,136-170 (1982).

9. Krippner, S. \& Uliman, M. J. nerv. ment. Dis. 151, 394 Krippner,

10. 一, Honorton, C. \& Ullman, M. J. Am. Soc. psychosom. ment. Med. 20, 9 - 17 (1973).

11. Ullman, M. Exp. Med. Surg. 27, 19 - 38 (1969).

12. -, Krippner, S. \& Feldstein, S. Int. J. Neuropsychiat. 2. $420-437(1966)$

3. - \& Krippner, S. Biol. Psychiat. 1, 259 - 270 (1969)

14. Wolman, B.B. (ed.) Handbook of Parapsychology (Van Nostrand Reinhold, New York, 1977

5. Child, I.L. Am. Psychol. 40, 1219 - 1230 (1985).

\section{Pesticide dangers}

SIR-J. Gordon Edwards (Nature 320, 391 ; 1986) has misunderstood Lord Ashby's review of Pesticides and Nature Conservation: The British Experience $1950-1975$ by John Sheail (Nature 318, $21 ; 1985)$; I cannot believe that he has read the book.

I agree that members of the "loony left" of the conservation movement deserve $\mathrm{J}$. Gordon Edwards' strictures, and I have myself criticized them for the past 30 years. But John Sheail's book describes the way in which scientific work in pesticides in Britain generally resulted in collaboration between industry, government and responsible conservation bodies, to introduce sensible controls of potentially dangerous chemicals. As director of the Nature Conservancy's Monks Wood Experimental Station at the time, I know that my colleagues certainly did not "resort to such unscientific methods as deliberately distorting or omitting all the data that refuted their allegations". The work has, of course, been published in reputable scientific journals.

Lord Ashby in his review implies that Rachel Carson's Silent Spring alerted the authorities and the public to the dangers of pesticides. That danger was already fully recognized, at least among scientists. In fact, in Britain the most important controls of pesticides that had been shown to have harmful ecological effects were introduced, with the fullest cooperation of the chemical industry, some months before Silent Spring was published.

Kenneth Mellanby Monks Wood Experimental Station, Huntingdon PE17 2LS, UK

\section{Ling defended}

SIR-The ill-natured and unnecessary sideswipe at Gilbert Ling (Nature 320, $318 ; 1986)$ by Peter Newmark needs to be answered. Ling, "a physiologist... who remains a voice in the wilderness", is the man whose pioneer work with Gerard on intracellular potentials initiated just about all the advances in neurophysiology of the past fifty years. Is it possible that Ling knows something about cell interiors that his critics are missing?

As for the sodium pump, Newmark could consult our papers in Nature which by some miracle escaped the greater excommunication. To my knowledge, no other papers critical of the peculiar and unlikely hypothesis of active transport "powered" by metabolic pumps have ever been accepted and published by either Nature or Science. Such unanimity in science is unreal.

110 West Oak Street,

Chicago, Illinois 60610, USA

1. Joseph et al. Nature 191, 1175 (1961); 203, 931 (1964); 206, 6 (1965); 209, 398 (1966). 